\title{
A CRUZ E O COMPASSO: UMA INTRINCADA RELAÇÃO HISTÓRICA
}

\section{THE CROSS AND THE COMPASS: A COMPLEX HISTORICAL RELATIONSHIP}

\author{
Fernando Monteiro* \\ Cláudia Neves da Silva**
}

\begin{abstract}
RESUMO
O presente trabalho tem por finalidade expor uma análise em andamento sobre o relacionamento conflituoso entre a Igreja Católica e a Maçonaria, ao longo de quase três séculos. A proposta é expor, à luz do novo Código de Direito Canônico, o que tem sido a Maçonaria para a Igreja Católica e a atitude desta em face da primeira. O conteúdo desta exposição assenta-se nos principais documentos expedidos pela Igreja Católica em desfavor dos maçons, entre os quais a bula In eminenti apostolatus specula, do papa Clemente XII, datada de 1738; o cânon 2.335 do Código de Direito Canônico de 1917; a "Carta de 1974"; o cânon 1.374 do novo Código de Direito Canônico e a Declaração da Sagrada Congregação para a Doutrina da Fé, datada de 1983. As páginas que se seguem se propõem a contribuir para a discussão de um tema que ainda hoje atrai a atenção de muitos que esperam ver as duas instituições definitivamente reconciliadas.
\end{abstract}

Palavras-chave: Maçonaria. Igreja Católica. Reconciliação. Código de Direito Canônico.

\begin{abstract}
This paper presents an ongoing analysis of the delicate relationship of nearly three centuries between the Catholic Church and Freemasonry. The paper intends to expose in the light of the new Code of Canon Law what Freemasonry has been to the Catholic Church and the attitude of Freemasonry towards the Catholic Church. The contents of this analysis is based on key documents issued by the Catholic Church to the detriment of the Masons, among them: the bull eminenti apostolatus specula of Pope Clement XII, dated 1738, canon 2335 of the Code of Canon Law of 1917, the "Charter of 1974" the canon of the new 1374 Code of Canon Law and the Declaration of the Sacred Congregation for the Doctrine of the Faith, dated 1983. The intention of the analysis is to contribute to the discussion of a subject that still attracts the attention of many who expect the two institutions to reconcile.
\end{abstract}

Keywords: Freemasonry. Catholic Church. Reconciliation. Code of Canon Law.

\footnotetext{
"Mestrando em Serviço Social e Política Social pela Universidade Estadual de Londrina/UEL. E-mail: fernandomonteiro@consesp.com.br

${ }^{* *}$ Mestre e Doutora em História pela Universidade Estadual Paulista/UNESP e Docente do Curso de Serviço Social da Universidade Estadual de Londrina/ UEL. E-mail: silva31101@hotmail.com
} 


\section{Introdução}

Durante o século XIX são várias as referências às ações da Maçonaria no Brasil. Apesar disso, com exceção de alguns estudos recentes a esse respeito, a história da Maçonaria ainda é muito pouco conhecida, não tendo chegado a se constituir em tema corrente de pesquisa acadêmica. $\mathrm{O}$ desinteresse em torno do pertencimento maçônico é, de certa forma, interessante pois, por um lado, há uma visibilidade dos maçons nas obras produzidas ao longo do século XIX; por outro, aqueles mesmos personagens históricos foram destituídos de sua identidade maçônica nos estudos de caráter acadêmico das últimas décadas. Não obstante algumas construções teóricas apontarem para o pertencimento maçônico de tal ou qual personagem, "o seu registro se assemelha a um daqueles adjetivos inseridos casualmente em uma frase e cuja retirada não faria a menor falta na medida em que pouco contribui para estabelecer o nexo explicativo de uma questão" (AZEVEDO, 1996-97, p.179).

Nesse contexto, a Maçonaria, como objetivo específico de análise, ainda é um tema pouco explorado pela academia em geral. As poucas referências a respeito, via de regra, são esparsas e fragmentadas. Poucos pesquisadores acadêmicos se debruçaram sobre a relação Igreja/Maçonaria. O caráter sigiloso em torno da Ordem dos pedreiros-livres, o mito do segredo e a obscuridade dos propósitos da Maçonaria de certa forma contribuem para o silêncio em torno dessa instituição, além de garantir a ela uma série de referências, entre as quais as que revelam a presença de um imaginário popular de obscuridade, pois "o tão divulgado caráter fechado ou secreto da Maçonaria pode ter inibido muitos profissionais a qualquer iniciativa" (COLISSI, 1998, p.12).

Os pesquisadores acadêmicos brasileiros, quando abordam a Maçonaria, fazem-no apenas no âmbito da história política brasileira. Esse vínculo direto entre Maçonaria e política contribui também para dificultar uma abordagem recorrente da instituição maçônica, pois

as abordagens sobre maçonaria, por ficarem restritas à esfera da história política, acabaram apresentando muitos dos problemas que levaram a que esse gênero histórico fosse marginalizado por boa parte da historiografia mundial a partir da década de 1930" (COLUSSI, 1998, p.19).
No âmbito brasileiro, a Maçonaria vem sendo trabalhada através de uma historiografia bastante comprometida do ponto de vista ideológico. Trata-se de uma historiografia construída por maçons e "antimaçons", que se dedicaram com afinco a restaurar a trajetória da instituição maçônica no Brasil, todavia, com objetivos diametralmente opostos: os primeiros, apologéticos, e os segundos, como fervorosos inimigos, contribuindo assim para a construção de um acervo de certo modo obscuro em torno da temática (COLUSSI, 1998, p.39).

Para fins de análise historiográfica, a bibliografia que se ocupa da instituição maçônica pode ser dividida em dois grupos: a bibliografia "descomprometida", que inclui os acadêmicos e não acadêmicos, ou tradicionais, e a bibliografia "comprometida", composta de obras escritas por maçons e antimaçons. É com base nesses dois tipos de historiografia propostos pela historiadora Eliane Lucia Colussi que trataremos da relação entre Igreja Católica e Maçonaria, cujo conflito já conta quase três séculos de existência.

\section{Um documento que entrou para a história}

No dia 28 de abril de 1738, o papa Clemente XII promulgou um documento que entrou para história: a bula In eminenti apostolatus specula. Trata-se de uma condenação pontifícia da Maçonaria, ocorrida apenas 21 anos depois da data que se costuma indicar como o início da Maçonaria moderna: 1717. A pergunta que fica é: quais razões, de fato, levaram a Igreja Católica a condenar uma sociedade de homens que ainda não era suficientemente conhecida das autoridades romanas daquele tempo?

Entre as várias tentativas de resposta, Alec Mellor, advogado, católico e estudioso da Maçonaria, iniciado na Ordem maçônica a 29/03/1969 sustenta que o motivo real da condenação não era religioso, mas ligado a questões políticas e à família real dos Stuart, destronada e refugiada em Roma, sob a proteção da Igreja. Mas não faltam controvérsias a respeito, pois para Benimeli, "esta hipótese, [é] totalmente insustentável do ponto de vista histórico, à luz da documentação vaticana da época" (HORTAL, 2002, p.7-8). 
Para Jesus Hortal, a própria bula do papa Clemente XII é um tanto obscura na sua redação. Um melhor resumo dela é feito na bula Providas Romanorum Pontificum, promulgada pelo papa Bento XIV, a 18/05/1751, cujo objetivo era também a condenação de toda e qualquer prática maçônica. Esse segundo documento, seguindo as mesmas diretrizes da condenação anterior, enumera seis razões para a condenação.

A primeira é que, nas tais sociedades e assembleias secretas, estão filiados indistintamente homens de todos os credos; daí ser evidente o grande perigo para a pureza da religião católica; a segunda é a obrigação estrita do segredo indevassável, pela qual se oculta tudo que se passa nas assembleias secretas; a terceira é o juramento pelo qual se comprometem a guardar inviolável o segredo; a quarta é que tais sociedades são reconhecidamente contrárias às sanções civis e canônicas; a quinta é que em muitos países as ditas sociedades maçônicas foram proscritas e eliminadas por leis de príncipes seculares; a última, enfim, é que as tais sociedades e agremiações são reprováveis por homens prudentes e honestos (1998, p.8-9).

Em uma leitura rápida, deixando de lado o segredo - sobre cuja natureza e conteúdo nada se diz nas condenações -, não há nada de verdadeiramente grave, capaz de justificar a pena de excomunhão cominada aos maçons. Contudo, Jesus Hortal assinala que num exame mais detido é possível vislumbrar motivos doutrinários mais profundos. O motivo real parece advir do "grande perigo para a pureza da religião católica", estampado no primeiro motivo, entre os aduzidos na bula papal.

Para Jesus Hortal, o problema mais profundo parece residir, portanto, na reunião de homens de diversas religiões e credos que poderá levar a considerar a religião católica apenas como mais um caminho possível entre tantos outros. Esses indiferentismo e relativismo religiosos, no século XVIII, eram comportamentos frequentes nos ambientes iluministas. O próprio fato da reunião de homens de diversas religiões não era nem é, em si, uma heresia, mas levantava a desconfiança da Igreja. O fato é que 250 anos após a primeira condenação, a posição da Igreja parece não ter mudado muito (HORTAL, 2002, p.7-10).
Como se verá nas linhas que seguem, a razão básica da última condenação, datada de 23/11/1983, continua a ser a mesma: a inconciliabilidade entre a afirmação sincera e plena da fé católica e o relativismo que parece ocultar-se atrás do universo simbólico maçônico.

\section{A Maçonaria: de agremiação de pedreiros a espaço especulativo}

É tarefa inútil tentar buscar o momento exato do aparecimento da Maçonaria, uma vez que suas origens se perdem num passado de mitos e lendas, remontando ao rei Salomão e outros personagens do Velho Testamento (AZEVEDO, 1996-97, p.180). É muito difícil saber onde termina o fato histórico e começa o mito, tendo em vista que ambos fazem parte do cotidiano vivido pelos maçons em suas reuniões, nos seus rituais, nas suas tradições, no seu imaginário e na sua identidade (MOREL; SOUZA, 2008, p.15). Há, no entanto, um ponto de concordância entre os pesquisadores quanto à filiação direta da Maçonaria moderna à antiga Maçonaria de ofício, dita operativa. "Tudo, porém, parece indicar uma evolução a partir das corporações de pedreiros, surgidas na Idade Média, para a construção de grandes catedrais góticas." (HORTAL, 2002, p.12.)

A historiadora Célia Marinho Azevedo aponta para a necessidade de compreensão das raízes etimológicas do termo francomaçonaria para um melhor entendimento das peculiaridades que cercavam as sociedades de francomaçons em relação a outras guildas existentes na Idade Média. A par dos artesãos congregados em ofícios regulares, a partir do século XIII, sob a égide do feudo ou de uma cidade, havia outros artesãos que não se submetiam a todas as obrigações locais, desfrutando da liberdade de circulação. Na época, o único poder existente capaz de conceder o privilégio das "franquias" era a Igreja Católica. E foi sob a sua tutela que se organizaram e desenvolveram essas confrarias laicas de artesãos privilegiados, conhecidos como Francs-mestiers, ffremason, masonfrre ou ffremaceons (1996-97, p.180).

Para os historiadores Marco Morel e Françoise Jean Souza, os homens ligados à arte da construção, em razão da natureza itinerante do seu trabalho, não se vinculavam a nenhuma cidade ou feudo 
e possuíam o privilégio da livre circulação, além de não se submeterem à servidão e ao pagamento de impostos. A origem do nome francomaçom ou pedreiro-livre é uma consequência desses privilégios, concedidos pela Igreja Católica. "A palavra 'franco' qualifica o indivíduo livre da servidão. Já a palavra 'maçom', originária do francês, língua oficial dos ofícios, quer dizer pedreiro, não só o operário, mas também os arquitetos, chamados mestres de pedraria." (2008, p.40). ${ }^{1}$

As finalidades das antigas corporações de ofício dos pedreiros-livres, todavia, ultrapassavam as questões puramente profissionais, uma vez que essas confrarias encontravam-se carregadas de conteúdos religiosos, perceptíveis através da adoção de símbolos cristãos e da estreita relação com o clero. Cada corporação de ofício possuía um santo padroeiro e a sua sede era estabelecida em uma igreja ou capela. "Além dos deveres religiosos que se impunham, os ofícios dos pedreiros-livres assumiam preocupações caritativas, como o socorro aos doentes e a missa para os mortos." (MOREL; SOUZA, 2088, p.40.)

Ao longo do século XV a Maçonaria operativa começa a entrar em declínio, e no século seguinte, quase deixa de existir, em especial devido à Reforma Protestante ocorrida na Inglaterra. Todas as corporações de ofício foram eliminadas por Henrique VIII. As catedrais já não eram mais erguidas, uma vez que aos olhos dos puritanos elas eram monumentos da religião católica e, portanto, consideradas perigosas, de modo que muitas delas foram desfiguradas ou parcialmente demolidas. A mesma investidura foi dirigida contra todas as outras estruturas de tipo semelhante, de modo que as velhas lojas de maçons construtores, que tinham surgido para erguer catedrais, viram-se sem trabalho (HAYWOOD, 2011, p.56).

A partir dos séculos XVI e XVII, as agremiações de pedreiros-livres começaram a admitir os chamados "membros aceitos", ou seja, homens não vinculados ao ofício da construção. Os maçons "aceitos" iniciavam na confraria interessados em participar de uma nova forma de sociabilidade, pois,

\footnotetext{
${ }^{1}$ Os principais símbolos maçônicos surgem do ofício da construção. $\mathrm{O}$ compasso e o esquadro simbolizam a prática da construção. Na Maçonaria moderna, o instrumento que desenha círculos perfeitos significa, para os maçons, a busca da perfeição interior, enquanto o esquadro, com seu ângulo reto, mostra a maneira reta que o maçom deve seguir na vida, pautando-se sempre na honestidade (ALMÉRI, 2007, p.24).
}

a essa altura, "as confrarias ofereciam a possibilidade de compartilhar entre si preciosos conhecimentos filosóficos e esotéricos". Como consequência dessa abertura, o elemento "aceito", foi se tornando cada vez mais numeroso, a ponto de o caráter operativo da ordem ser substituído por uma finalidade de natureza puramente especulativa (MOREL; SOUZA, 2008, p.41).

Contribui também para o fim da Maçonaria operativa o fato de o estilo renascentista ter posto um ponto final nas majestosas construções da Idade Média. O novo estilo de construção, mais simples e menos dispendioso, acabou por substituir vantajosamente o difícil e complexo estilo ogival, fazendo com que a corporação dos pedreiros-livres declinasse aos poucos, até entrar em franca decadência ( ASLAN, 1997, p.16).

Além disso, há o desenvolvimento dos estudos e a formação de verdadeiras escolas de arte na Renascença, onde o segredo da construção acaba por se tornar sem efeito. A arquitetura passa a ser estudada em tratados impressos e não apenas através da transmissão oral dos conhecimentos dos mestres-maçons, fazendo com que as lojas de pedreiros-livres perdessem a razão para existir (HORTAL, 2002, p.13).

No começo do século XVII, percebe-se na Inglaterra e na Escócia uma manobra para garantir a sobrevivência dessas lojas de pedreiros, já bastante desgastadas pelo malogro da construção. Grande parte dos historiadores concorda que as feições da Maçonaria moderna ou especulativa remontam a 1717, marco da fundação da Grande Loja de Londres, que converteu a Maçonaria em uma espécie de escola de formação humana de caráter universal e secreto, reunindo homens de diferentes raças, religiões e línguas com o objetivo de alcançar a perfeição por meio do simbolismo de natureza mística e/ou racional, da filantropia e da educação (BARATA, 1994, p.78-99).

Para o padre Jesus Hortal, “A Maçonaria moderna, considerada para além das lendas e dos mitos, é fruto, talvez o mais representativo, do Iluminismo". Assim, não é sem razão que na Maçonaria é possível ver duas características do Iluminismo: “a confiança absoluta nos poderes infalíveis da razão humana e da experiência, e o sentimento da imensidão da natureza, governada pelas leis férreas do 
mecanicismo, nem sempre favoráveis ao homem". Segundo o autor, as lojas maçônicas, sob o manto do segredo, prestavam-se perfeitamente à difusão das ideias iluministas, quase sempre consideradas como subversivas pelos governos civis.

No fundo, trata-se do [...] ideal iluminista que pretendia dissipar as trevas de um mundo ensombrecido pela ignorância, mediante o esforço inteligente do ser humano, capaz, por si só, de atingir a verdade. (2002, p.35-6).

A ideia do quanto o pensamento iluminista penetrou na Maçonaria pode ser percebida através de algumas palavras constantes da instrução para aprendiz-maçom. O presidente da Loja dá ao iniciando no primeiro grau a seguinte instrução:

O deísmo, ou teísmo [sic!], é a crença na existência de Deus sem revelação nem culto. É a religião da razão, a religião dos grandes espíritos de todos os tempos, de todos os lugares, a religião que será professada por todos os povos da terra quando eles formarem uma só nação e uma única família; a religião do futuro, destinada a substituir os cultos tão numerosos que desfiguram a Divindade em todos os pontos do globo. (HORTAL, 2002, p.20).

No ritual do segundo grau, o de companheiro-maçom, acrescenta-se:

A filosofia liberta o espírito de toda crença vã, de todo preconceito, de toda superstição; estudá-la é querer ser livre. Por ela, chegamos ao domínio de nós mesmos. Quem é iluminado por essa ciência tem a certeza de ser superior às próprias paixões; aprende que as paixões devem ser servas e não senhoras da razão. (HORTAL, 2002, p.20).

\section{Maçonaria: uma breve definição}

O que é efetivamente Maçonaria? Essa pergunta recebeu, ao longo dos séculos, de amigos e inimigos, as mais variadas respostas. O Grande Oriente do Brasil (GOB), órgão responsável pela administração de lojas maçônicas sob sua jurisdição, conceitua a Maçonaria como uma instituição essencialmente filosófica, filantrópica, educativa e progressista.

Filosófica porque em seus atos e cerimônias ela trata da essência, propriedade e efeitos das causas naturais, investigando as leis da natureza, e re- laciona as primeiras bases da moral e da ética pura. É filantrópica porque não está constituída para obter lucro pessoal de nenhuma classe; antes, pelo contrário, suas arrecadações e seus recursos se destinam ao bem-estar do gênero humano, sem distinção de nacionalidade, sexo, religião ou raça, procurando conseguir a felicidade dos homens por meio da elevação espiritual e pela tranquilidade da consciência.

É progressista, pois, partindo do princípio da imortalidade e da crença em um princípio criador regular e infinito, não se apega a dogmas, prevenções ou superstições e não põe nenhum obstáculo ao esforço dos seres humanos na busca da verdade, nem reconhece outro limite nessa busca senão o da razão com base na ciência.

Seus princípios são a liberdade, a igualdade e a fraternidade. A liberdade dos indivíduos e dos grupos humanos; a igualdade de direitos e obrigações dos seres e grupos sem distinguir a religião, a raça ou a nacionalidade; a fraternidade de todos os homens, já que são todos oriundos de um mesmo criador, chamado de o Grande Arquiteto do Universo (GRANDE ORIENTE DO BRASIL, 2011, p.1).

Já numa perspectiva acadêmica, Eliane Colussi define a Maçonaria como uma:

[...] associação fraternal, possuidora de uma organização em ritual e símbolos na qual o segredo ocupa papel fundamental. É uma instituição que foi e permanece sendo acessível principalmente ao sexo masculino e que tem por objetivos o aperfeiçoamento intelectual da sociedade, de seus filiados, e a promoção da ação filantrópica interna e externa; caracteriza-se por não orientar política e religiosamente seus membros. (apud SILVA, 2009, p.77).

\section{O segredo maçônico}

No interior do Estado Absolutista, as lojas maçônicas, protegidas pelo sigilo, representavam a formação típica de um "poder indireto", exercido pela nova burguesia. Nas confrarias maçônicas e através delas a burguesia articulava uma forma social própria e vivia de acordo com suas "próprias" leis. Entretanto, essa verdadeira "liberdade civil" praticada no interior das lojas maçônicas, no contexto do Antigo Regime, só era possível sob a proteção do segredo. Dessa forma, 
O Secreto criava um novo gênero de comunidade, onde o 'mistério' era o cimento da fraternidade e uma forma de educação moral, forjada no compromisso fundamental de guardar segredo (BARATA, 1994, p.80-1).

Patrícia Inês Garcia de Souza defende que o segredo na Maçonaria, a partir dos sinais de reconhecimento de um maçom, engendra o sentido de comunidade. Signos simbólicos e secretos são realizados entre maçons que sequer se conhecem, mas se reconhecem como irmãos, resultando na delimitação de uma fronteira, pois "marca-se um território imaginário pela ideia do 'nós' (maçom) em separação aos 'outros' (não maçons). Assim, o segredo está presente em diversos aspectos na Maçonaria, seja ele interpretado como um conteúdo, um princípio ético ou como uma técnica,

ele estrutura e unifica uma comunidade, demarcando-lhe fronteiras e garantindo-lhe a continuidade de uma tradição, mesmo que esse segredo, como um conteúdo, nem exista (2006, p.94-5).

Jesus Hortal, também analisando o aspecto secreto das reuniões maçônicas, conclui que em todos os ritos de iniciação existe a exigência feita ao iniciado, de guardar segredo absoluto sobre o que lhe foi comunicado. De maneira semelhante, isso acontece na Maçonaria, uma vez que "o primeiro e capital dever do maçom é ser discreto e manter o mais absoluto silêncio acerca de tudo quanto ouvir, aprender e descobrir em reuniões e trabalhos maçônicos, quaisquer que sejam eles". A obrigação do segredo, diz o pesquisador, é, na Maçonaria, um dado inquestionável, por se tratar de um segredo iniciático, ou seja, "destinado a proteger um pretenso conhecimento oculto, aperfeiçoador da pessoa humana, que seria transmitido nas iniciações maçônicas". Não se trata de conhecimento fixado em fórmula, e sim uma espécie de viagem espiritual que o iniciado faz. "Daí que o segredo maçônico acabe sendo algo tão pessoal e íntimo, que se torna realmente incomunicável." (2002, p.26-7).

Benimeli, Caprile e Alberton, tratando da mesma temática, sustentam que os segredos (no plural) são as palavras, sinais e toques pelos quais os maçons se reconhecem entre si e se distinguem dos demais homens. O segredo (no singular) é um conceito absolutamente filosófico, de conteúdo variável, entendido por alguns como o estado de iluminação interior atingido pela iniciação e que a linguagem humana não saberia traduzir (1998, p.348).

\section{As ideias iluministas e o anticlericalismo maçônico}

Jesus Hortal, ao analisar o tipo de ideologia existente ao tempo do surgimento da Maçonaria moderna, sustenta que a Maçonaria, na sua forma atual, surgiu na Inglaterra na aurora do século XVIII, onde florescia a filosofia deísta e empirista, junto com um sistema peculiar de governo, limitadamente democrático, tipicamente burguês. Por outro lado, a religião anglicana, mesmo mantendo fortes restrições em face dos católicos, mas confrontada com uma diversidade crescente de comunidades protestantes, propiciava certo espírito de tolerância.

Dessa forma, é evidente que, na Grã-Bretanha, onde se encontravam pessoas de diversas religiões, a Maçonaria não se chocasse nem com a mentalidade dominante, nem com as instituições sociais. A própria dinastia de Orange, ao que parece, utilizou a Maçonaria como veículo político de luta contra os Stuart, que se encontravam refugiados no continente e que pretenderam organizar uma Maçonaria rival, a jacobita.

Além disso, a Grã-Bretanha daquele momento já havia realizado sua revolução burguesa, com a instauração de uma nova dinastia. Consequentemente, a Inglaterra permanecerá à margem dos movimentos sociais europeus, oriundos da Revolução Francesa. Por outro lado, não sendo um país católico e não tolerando em seu território a Companhia de Jesus, a Inglaterra não experimentará também o mesmo tipo de anticlericalismo, em especial o antijesuitismo das cortes baurbônicas.

Por outro lado, como ressalta Hortal, nos países latinos, o racionalismo típico do "Século das Luzes" vai confrontar-se com a mentalidade católica e, de modo especial, com a educação humanista dos colégios jesuíticos, que ocupavam lugar de destaque no ensino. Daí nasce o conflito entre Igreja Católica e Iluminismo, e, por via de consequência, entre Igreja Católica e Maçonaria. O Iluminismo é um dos fenômenos mais característicos do que se pode denominar "espírito moderno". Apesar de nascer e morrer no século XVIII, 
a problemática proposta pelo Iluminismo ainda tem importância nos nossos dias.

Hortal (2002, p.29-33) aponta que as questões levantadas pelo Iluminismo não eram totalmente inéditas, uma vez que já se encontravam presentes na Renascença. Todavia, o ponto central da proposta iluminista repousava no problema dos limites da autonomia humana, da capacidade do homem de atingir, por si só, o conhecimento verdadeiro e de conseguir, com seus próprios meios, a perfeição moral. $\mathrm{O}$ pesquisador ressalta que, ao tempo da Renascença, contudo, essa temática revestia-se ainda de características cristãs, "enquanto no Iluminismo atingiu os limites da descrença, do agnosticismo e do radicalismo ateu, que, na segunda metade do século XVIII, se tornou moda nos salões elegantes de Paris".

O Iluminismo, para Hortal, deu ensejo a um anticlericalismo feroz. "O expoente mais evidente dessa atitude é Voltaire, gênio universal, mas ofuscado pela ideia de destruir a Igreja Católica, o 'infame' como ele a denominava." Ao tempo do Iluminismo desenvolveu-se a ideia de uma religião natural, fundada na razão, na pura dedução lógica, "uma religião capaz de dar certezas humanas, não divinas". O problema está em que “

desse modo, na concepção iluminista - e consequentemente na maçonaria - Cristo fica reduzido ao papel de um simples pensador, genial sim, mas desprovido de qualquer missão divina. A Igreja perde então o seu papel (2002, p.29-33).

Como consequência, diz o mesmo autor, "A revelação divina é degradada à categoria de mito. O dogma, o sacerdócio, o culto cristão são ridicularizados. Os mais audazes iluministas se proclamavam ateus, sem rebuços". Não foi apenas a Ordem dos pedreiros-livres que bebeu na fonte do "Século das Luzes". No século seguinte, o positivismo, que tanta influência exerceu no Brasil, acolheu essa concepção de religião natural e desenvolveu-a como "religião positivista", da qual ainda se encontra vestígios nos "templos positivistas", nos dias de hoje totalmente vazios, espalhados por diversas cidades brasileiras.

"Uma última característica do Iluminismo é o olhar de desprezo sobre o passado. A Idade Média passa a ser conhecida como 'Idade das Trevas', por oposição ao século XVIII, o 'Século das Luzes'." Há uma série de convergências entre Maçonaria e Iluminismo, as quais possibilitaram a ação conjunta de iluministas e maçons em diversos campos. E é justamente isso que vai despertar a insatisfação e desconfiança da Igreja Católica em relação à Maçonaria (2002, p.29-33).

\section{Os pedreiros-livres na visão de outras Igre- jas cristãs}

Não raro ressoa o argumento de que apenas a Igreja Católica se mostra intransigente em relação aos maçons. Porém, para Jesus Hortal, "Essa afirmação não é correta". Para ele, os pronunciamentos de outras Igrejas sobre a Ordem maçônica são bem menos numerosos do que os da Igreja Católica, mas isso devido, em grande parte, ao fato de somente a Igreja Católica possuir um comando central, com jurisdicional válida para todo o mundo.

Para Hortal (2002, p.73-9), a Igreja da Inglaterra (anglicana) possui estreitas relações com a Maçonaria. No Brasil, vários ministros da Igreja Episcopal Anglicana são ou foram maçons. Mas, apesar dos laços históricos, em 1986 uma comissão especial anglicana de sete membros, incluindo dois maçons, publicou um documento com o título "Franco-Maçonaria e Cristianismo são compatíveis?". "A conclusão a respeito era claramente negativa por basear-se na tese defendida pelos maçons de que o homem é totalmente responsável por sua própria salvação, pouco importando o papel da graça divina."

Em 1985, a Igreja Metodista [da Inglaterra] se insurgiu contra o sincretismo anticristão da Maçonaria. As Igrejas Evangélicas norte-americanas do Missouri e do Wisconsin já haviam se pronunciado na mesma linha em 1967. A Igreja ortodoxa mantém a declaração contra a Maçonaria, publicada em 12 de outubro de 1933. A Igreja Católica Apostólica Ortodoxa Antioquena mantém, no Brasil, a mesma posição de condenação à Maçonaria. Na Holanda, em 20 de maio de 1989, o Sínodo Geral da Igreja Presbiteriana da Escócia aprovou um texto dirigido aos maçons pertencentes à Igreja, convidando-os a se retirarem da Maçonaria, em razão da incompatibilidade entre Maçonaria e fé cristã.

O fundador da Igreja de Jesus Cristo dos Santos dos Últimos Dias (mórmons), Joseph Smith, foi iniciado na Maçonaria, mas posteriormente a Igreja 
desencorajou a iniciação de seus membros na Ordem maçônica. As três principais Igrejas luteranas dos Estados Unidos (American Lutheran Church, Lutheran Church Missouri Synod, Lutheran Church in America) proíbem que seus pastores se iniciem na Maçonaria. Na Convenção Batista do Sul, a maior denominação protestante dos Estados Unidos, ergueram-se recentemente vozes que pediam a declaração de incompatibilidade entre Maçonaria e fé cristã.

No Brasil, segundo Hortal (2002, p.73-9), é possível ver posições antimaçônicas entre as Igrejas protestantes históricas. A Igreja Evangélica de Confissão Luterana no Brasil é tradicionalmente contrária à Ordem maçônica, embora não tenha se manifestado publicamente a respeito. A Igreja Presbiteriana Independente também mantém firme atitude antimaçônica. A Assembleia Geral da Igreja Presbiteriana do Brasil, reunida em Valença (Rio de Janeiro), em 1916, declarou que "esta Igreja 'jamais reconheceu e não reconhece a compatibilidade da Maçonaria e da profissão do Evangelho'. Por fim, Hortal admite não ter notícia em relação à posição das outras Igrejas brasileiras na questão maçônica e conclui que, de certo, existem numerosos pastores maçons na Igreja Metodista e na Episcopal (Comunhão anglicana), como também há alguns que sustentam posições claramente antimaçônicas. Faltam, porém, pronunciamentos oficiais das Igrejas.

\section{Igreja católica e maçonaria: uma relação dolorosa}

Se a Maçonaria operativa manteve estreitos laços com a Igreja Católica, gozando inclusive dos privilégios das franquias, o mesmo não aconteceu em relação à Maçonaria moderna, chamada especulativa, inaugurada em 1717, com a fundação da Grande Loja de Londres, eleita desde cedo pela Igreja Católica como sua principal inimiga. A forma secreta de reunião, o sigilo sobre tudo o que ali se passava, o deísmo religioso, a propagação dos ideais iluministas e a grande adesão que provocou, renderam-lhe a oposição do clero e de alguns governos civis.

A primeira condenação pontifícia da Maçonaria deveu-se a Clemente XII, na sua Carta Apostólica In eminenti, datada de 28/04/1738. O mesmo fizeram Bento XIV, alguns anos mais tarde, a 18 de maio de 1751, com a Constituição Providas; Pio VII, com a Constituição Ecclesiam a Jesu Christo (13/09/1821); Leão XII, com a Constituição Quo graviora (13/03/1825); Pio IX, com a Constituição Qui pluribus (09/11/1846), com a alocução Quibus quantisque (20/04/1849), com a constituição Nostris et nobiscum (08/12/1849), com a Encíclica Quanta cura (08/12/1864), com a alocução Multiplices inter (25/09/1865), com a Constituição Apostolicae Sedis (12/10/1869), com a Carta Quamquam (29/05/1873), com a Carta Exortae (29/04/1876); e depois Leão XIII, com a Encíclica Humanum genus (20/04/1884) (BENIMELI; CAPRILE; ALBERTON, 1998, p.23). Parte da condenação de Clemente XII diz o seguinte:

Homens de todas as religiões e seitas, sob a aparência de honestidade natural, por um pacto estreito e impenetrável, conforme leis e estatutos por eles criados, obrigando-se sob juramento, pronunciado sobre a Sagrada Escritura e sob penas graves a ocultar, por um silêncio inviolável, tudo o que praticam nas sombras do segredo'. Acentuava-se, por outra, que suas associações ou conventículos, geraram no espírito dos fiéis suspeitas tão sérias, que quem faz parte delas fica marcado aos olhos das pessoas probas e prudentes, com o ferrete da malícia e da perversidade. E estas suspeitas cresceram de tal maneira que, em vários Estados, as referidas sociedades já há tempo foram proscritas e banidas, como elemento perigoso à segurança dos reinos. Por isso, "ponderando sobre os males tão grandes, que por via de regra resultam dessa espécie de sociedade ou conventículos, não somente para a tranquilidade dos estados temporais, mas inda para a salvação das almas, pois de maneira alguma podem harmonizar-se com as leis civis e canônicas...e por outras causas justas e razoáveis por Nós conhecidas, ... resolvemos e decretamos condenar e proibir as mencionadas sociedades, assembleias, reuniões, corrilhos ou conventículos de franco-maçons." [...] "Proibimos, portanto, seriamente, em nome da santa obediência a todos e a cada um dos fiéis de Cristo, de qualquer estado, posição, condição, classe, dignidade, e preeminência que sejam; leigos ou clérigos, seculares ou regulares, ousar ou presumir entrar, sob qualquer pretexto, debaixo de qualquer cor, nas sociedades de franco-maçons, propagá-las, sustentá-las, recebê-las em suas casas, ou dar-lhes abrigo [...]. (BENIMELI, CAPRILE, ALBERTON, p.23-5). 
As condenações da Maçonaria pelos papas dos últimos três séculos são numerosas e contínuas. Contam-se nada menos do que 580 documentos pontifícios a esse respeito. Leão XII, na constituição apostólica Quo graviora, de 13/03/1825, condenou genericamente todas as sociedades secretas. Precisamente nesse documento aparece pela primeira vez a formulação que passará para o primeiro Código de Direito Canônico: a de considerar a Maçonaria como uma sociedade que tem como finalidade $m a$ quinar (conspirar) contra a Igreja e os legítimos poderes do Estado. De Pio IX a Leão XIII encontram-se aproximadamente 350 pronunciamentos contra os maçons, cujo argumento central repousa no fato de serem as lojas maçônicas um local apropriado para conspirações contra a Igreja e os regimes monárquicos (HORTAL, 2002, p.45-6).

O historiador Alexandre Mansur Barata sustenta que a Igreja Católica condenou uma associação que, de fato, conhecia muito pouco, não sabia o que era, nem quais eram seus objetivos. Acrescenta que Clemente XII ao condenar e proibir a Maçonaria, em 1738, não foi nada original, pois na medida em que a Ordem dos pedreiros-livres começou a se expandir pela Europa, vários governos seculares, tanto católicos como protestantes, receosos em relação ao seu caráter secreto, adotaram medidas para coibi-la, como Holanda (1735), Genebra (1736), França (1737), Suécia e a cidade de Hamburgo (1738) (2006, p.127-8).

Barata destaca ainda que as motivações de Clemente XII para condenar e proibir a ação da Maçonaria podem ser resumidas da seguinte forma: numa perspectiva teológica, por considerar a Maçonaria contrária aos princípios da Igreja Católica ao congregar homens de todas as religiões; numa perspectiva moral, na medida em que o segredo que cercava a sociedade de franco-maçons era um mecanismo para encobrir as maldades e as perversões praticadas pelos maçons; e, numa perspectiva política, por ver o papa no segredo maçônico um perigo que deveria ser obstado.

Vista sob esse prisma, a condenação da Maçonaria pela Igreja Católica "somou ao conjunto de justificativas utilizadas como de 'razão de estado' para repressão aos maçons, um fundamento de natureza religiosa". Não eram apenas os governos civis que estavam ameaçados pelas reuniões secretas dos maçons, mas também a fé católica, "o que no caso português significou a inclusão do pertencimento à maçonaria no rol dos crimes circunscritos à jurisdição inquisitorial" (2006, p.127-8).

Em 1917 é promulgado o primeiro Código de Direito Canônico. Nele mantém-se a proibição de católicos inscreverem-se nas associações maçônicas, com a mesma motivação tradicional, pois, segundo o cânon 2.335,

os que dão seu nome à seita maçônica ou a outras associações que maquinam contra a Igreja ou contra os legítimos poderes civis, incorrem, pelo próprio fato, em excomunhão simplesmente reservada à Sé Apostólica.

Dessa forma, o Código Canônico estabelecia uma presunção de direito: a ação conspiratória ( $m a-$ chinatio) contra a Igreja e o Estado seria algo característico dos maçons e não precisaria de comprovação prática. Mas o diploma legal editado pela Igreja Católica não se contentou em cominar a pena de excomunhão. Para os religiosos maçons, estabelecia ainda uma série de suspensões e privações, além de impor a obrigação e denunciá-los ao Santo Ofício.

Alguns católicos lançam argumentos em defesa da Maçonaria, sustentando que nunca viram nem ouviram qualquer tentativa de conspiração contra a Igreja ou contra os legítimos poderes civis. Mas em outras fileiras, também católicas, ecoam vozes que disseminam a ideia da Maçonaria como um aglomerado de maquinadores, compenetrados em tramar conspirações tenebrosas contra tudo, em especial, contra a Igreja Católica. "O Código de Direito Canônico de 1917 parece ir nessa direção, quando fala de maquinação." Mas em que consistia essa machinatio, cujo protótipo eram as associações maçônicas? (HORTAL, 2002, p.48).

Os principais canonistas interpretam a palavra latina machinatio como não significando necessariamente o planejamento de ações concretas, com vistas a destruir a Igreja Católica e os legítimos poderes civis. Poderia tratar-se de uma machinatio ideológica, ou seja, da transmissão sistemática de ideias que entrassem em conflito com as verdades católicas, mesmo que isso não fosse dito abertamente. Existe a machinatio, escreve Regatillo, citando uma declaração do Santo Ofício, de 10/05/1884 - 
se [a sociedade] pretende violar a liberdade e os direitos da Igreja, afastar os fiéis dela, relaxar a disciplina, subverter, por meios ilícitos, tanto aberta quanto clandestinamente, a organização social, a forma legítima de governo ou a seguridade do Estado.

Não era preciso que a Maçonaria tivesse por objetivo fazer tudo isso; bastava esse "pretender afastar os fiéis da Igreja" para que pudesse ser enquadrada na condenação geral. O protótipo dessa maquinação era, conforme o Código de Direito Canônico de 1917, a Maçonaria (HORTAL, 2002, p.49).

\section{O Concílio Vaticano II e a "Carta de 1974": uma tentativa de alcançar a paz}

É importante saber como o problema maçônico se apresentava para a Igreja Católica no momento do Concílio. Em fins do século XIX e início do XX, em diversos países o episcopado viu-se constrangido a denunciar os abusos cometidos pela Igreja contra os grupos maçônicos. $\mathrm{Na}$ medida em que nos aproximamos dos nossos dias, nota-se, paulatinamente, uma sensível diminuição do número de documentos que condenam as práticas maçônicas. Os poucos documentos publicados foram inspirados em acontecimentos locais e fundados nos precedentes documentos pontifícios (BENIMELI, CAPRILE, ALBERTON, 1998, p.95).

O crescente silêncio em torno da Maçonaria poderia ser sinal de que o episcopado não via mais na Ordem dos pedreiros-livres o perigo de outrora, contra o qual teve, reiteradas vezes, de alertar os fiéis em tempos passados. Poderia também indicar que da parte da Maçonaria muitas das atitudes antieclesiásticas e anticlericais vinham sendo aos poucos abandonadas, ou, ao menos, refreadas.

Após a Segunda Guerra Mundial, são poucos os documentos episcopais que reiteram a excomunhão contra os maçons. Ao contrário, nota-se uma atitude mais possibilista por parte da Igreja Católica. É bastante significativo o conteúdo das propostas que chegaram à Secretaria da Comissão antepreparatória do Concílio Vaticano II, com relação à Maçonaria. Benimeli, Caprile e Alberton chamam atenção para o fato de que
Sobre 1.998 respostas de bispos e superiores, somente 15 mencionaram a Maçonaria, e destes somente 10 pediam que fossem novamente condenadas. (BENIMELI, CAPRILE, ALBERTON, 1998, p.96).

Durante o Concílio Vaticano II, dom Sérgio Méndez Arceo, então bispo de Cuernavaca, no México, na fala de 6/12/1962, pediu a revisão da posição da Igreja Católica em relação à Maçonaria. No dia 20/11/1963 o bispo mexicano retoma a fala sobre a Maçonaria, argumentando em favor da aproximação entre católicos e maçons, defendendo uma nova atitude pastoral em face da Maçonaria, ao sustentar a possibilidade do reconhecimento de maçonarias que não maquinam contra a Igreja e os poderes do Estado (HORTAL, 2002, p.56). Eis parte da fala de d. Méndez:

Parece-me que convém tratar também de uma questão da qual já falei no ano passado, e que diz respeito a homens de diferentes religiões reunidos numa associação cujos princípios, como nos ensina a História, foram cristãos, e que hoje, em parte, mantém-se e se renova como cristã. Dever-se-ia revogar as leis que, contra tais associações, a Igreja decretou, não poucas vezes, a fim de não separar da Igreja o bem do mal, indo contra a doutrina de nosso Senhor que nos ensinou ser preciso conservar a erva má para não arrancar junto com ela o bom grão. Refiro-me à sociedade dos maçons, entre os quais se encontram, certamente, ainda, um bom número de anticristãos, mas entre eles se encontram, ainda, muitos que acreditam em Deus e em sua Revelação, e que se honram de ser cristãos, ou, ao menos, abstêm-se de toda conspiração contra a Igreja ou contra as autoridades civis. Há entre eles os que aguardam uma palavra da Igreja. (BENIMELI, CAPRILE, ALBERTON, 1998, p.98).

Essas duas intervenções de d. Méndez não encontraram ressonância no Concílio, mas, por outro lado, não levantaram reações contrárias. Na reunião de 21 a 23 de outubro de 1969, bispos de toda a Escandinávia (Suécia, Noruega, Dinamarca, Finlândia e Islândia) decidiram defender a mesma ideia de maçonarias que não conspiram contra a fé cristã. Nas Filipinas, encontros entre representantes da Igreja e da Maçonaria levaram a uma série de conclusões que pareciam mostrar uma conciliabilidade entre o "ser" católico e a filiação às lojas maçônicas. 
Nesse início de diálogo, o cardeal König, sucessor de Innitzer no Arcebispado de Viena, conseguiu formar uma comissão mista católico-maçônica, que acabou produzindo um documento conhecido como "Declaração de Lichtenau", assinada por nove maçons e três teólogos católicos dos países de língua alemã, destinada ao papa Paulo VI e ao prefeito da Sagrada Congregação para a Doutrina da Fé, cardeal Seper, que, como contribuição para o estudo de ulteriores medidas, propugnava a abolição das condenações canônicas à Maçonaria (HORTAL, 2002, p.56).

Como os acontecimentos se precipitavam, tornava-se necessária uma tomada de posição por parte das instâncias superiores da Santa Sé. Mesmo que ainda fosse prematura a publicação de uma decisão definitiva, a 19/07/1974 a Sagrada Congregação para a Doutrina da Fé enviou ao cardeal John Krol e a algumas Conferências Episcopais uma carta sobre a questão que envolvia a relação Igreja/Maçonaria. Após lembrar as consultas realizadas por $\mathrm{m}$ uitos bispos acerca da interpretação do cânon 2.335 do Código Canônico de 1917, que impunha a pena de excomunhão aos católicos que se filiassem à Maçonaria, a chamada "Carta de 1974", prosseguia:

Durante o longo exame da questão, a Santa Sé consultou diversas vezes as Conferências Episcopais interessadas de modo particular pelo assunto, a fim de tomar conhecimento mais acurado tanto da natureza e da atuação da Maçonaria em nossos dias quanto do pensamento dos Bispos a respeito. A grande divergência de respostas, pela qual transparecem as situações diferentes de cada nação, não permitiu à Santa Sé mudar a legislação vigente, a qual, por isto, continua em vigor, até que nova lei canônica seja publicada pela competente Comissão Pontifícia para a revisão do Direito Canônico. No entanto, no exame dos casos particulares, é necessário levar em consideração que a lei penal está sujeita a interpretação estrita. Por conseguinte, pode-se ensinar e aplicar, com segurança, a opinião daqueles autores segundo os quais o cânon 2.335 se refere unicamente aos católicos que dão o nome às associações que de fato conspiram contra a Igreja. Em qualquer situação, porém, continua firme a proibição aos clérigos, aos religiosos e aos membros dos Institutos Seculares, de darem o nome a quaisquer associações maçônicas (HORTAL, 2002, p.58-9).
O teor da "Carta de 1974" é de alcance um tanto limitado. Restringe-se à interpretação do cânon 2.335, sem fazer qualquer menção aos demais dispositivos canônicos que se ocupam da Maçonaria. Ademais, sequer declara abolida a pena de excomunhão para os que dão o nome à Maçonaria. Apenas afirma que, de acordo com os princípios gerais da legislação canônica, essa pena nem sempre se aplicava. Não se verificando uma maquinação ( $m a-$ chinatio) de fato, a pena não deveria ser aplicada. Todavia, a carta "Parecia insinuar o desejo de mudança, mas também transparecia a insuficiência para tanto dos dados recolhidos até o momento". Por essa razão, a Sagrada Congregação para a Doutrina da Fé declarava que a legislação vigente, relativa à Maçonaria continuava em vigor, e, para confirmar essa vigência, lembrava as proibições para os clérigos e os membros dos institutos de vida consagrada. (HORTAL, 2002, p.58-9).

\section{O novo código de direito canônico}

No dia 25/01/1983 foi promulgado o novo Código de Direito Canônico. Já não havia nele qualquer referência explicita à Maçonaria. O polêmico cânon 2.335 foi substituído pelo cânon 1.374 , com a seguinte redação:

Quem se inscreve em alguma associação que maquina contra a Igreja seja punido com justa pena; e quem promove ou dirige uma dessas associações seja punido com interdito. (BENIMELI, CAPRILE, ALBERTON, 1998, p.224).

A imposição da "justa pena" não era mais automática, mas ficava a critério do juiz ou da autoridade administrativa competente, que, de acordo com o que se dizia na Carta da Sagrada Congregação para a Doutrina da Fé de 1974, deveria aplicá-la apenas se ficasse comprovado que uma determinada associação maquina contra a Igreja Católica. Com isso, católicos simpáticos à Maçonaria viram, nessa redação, como que uma confirmação de suas afirmações. "Se não está mais penalizada com excomunhão automática a inserção na Maçonaria argumentavam -, segue-se que é licito ao católico inscrever-se nela." (HORTAL, 2002, p.67-8).

Como essas interpretações aparecem por toda parte e havia muitos católicos esperando a entrada 
em vigor do novo Código de Direito Canônico para se inscreverem na Maçonaria, a Sagrada Congregação para a Doutrina da Fé, agora sob a direção do cardeal Ratzinger, viu-se obrigada a intervir outra vez no assunto. Em 26 de novembro de 1983, na véspera da entrada em vigor do novo Código, publicou uma Declaração sobre as associações maçônicas, com o seguinte teor:

Foi perguntado se mudou o parecer da Igreja a respeito da Maçonaria, pelo fato de que no novo Código de Direito Canônico ela não vem expressamente mencionada como no Código anterior. Esta Sagrada Congregação quer responder que tal circunstância é devida a um critério redacional seguido também quanto às outras associações igualmente não mencionadas, uma vez que estão compreendidas em categorias mais amplas. Permanece, portanto, imutável o parecer negativo da Igreja a respeito das associações maçônicas, pois os seus princípios foram sempre considerados inconciliáveis com a doutrina da Igreja e por isso permanece proibida a inscrição nelas. Os fiéis que pertencem às associações maçônicas estão em estado de pecado grave e não podem aproximar-se da Sagrada Comunhão. Não corresponde às autoridades eclesiásticas locais pronunciarem-se sobre a natureza das associações maçônicas com um juízo que implique derrogação do quanto acima estabelecido e isto segundo a mente da declaração desta Sagrada Congregação. O Sumo Pontífice João Paulo II, durante a audiência concedida ao subscritor Cardeal Prefeito, aprovou a presente Declaração, e ordenou a sua publicação. (HORTAL, 2002, p.67-8).

Essa Declaração, emitida pela mais alta autoridade em questão doutrinária, a Sagrada Congregação para a Doutrina da Fé, com a anuência do papa João Paulo II, declara a incompatibilidade entre os princípios da Maçonaria e a doutrina da Igreja Católica. Além disso, a partir dela as Conferências ficavam proibidas de se pronunciarem com um juízo que implique derrogação das normas dadas.

Ficava também claro que não se poderia defender uma suposta compatibilidade entre Igreja Católica e Maçonaria, com base na omissão da pena de excomunhão no novo Código. (HORTAL, 2002, p.69-70.)

\section{Conclusão}

O centro da discussão consiste em perguntar se, face ao novo Código de Direito Canônico (cân. 1.374), os católicos continuam impedidos de ingressarem na Maçonaria ou estão impedidos tão somente de se inscreverem na Maçonaria que "maquina" contra a Igreja Católica.

Ao que parece estão impedidos de dar o nome à Maçonaria, independentemente de ela conspirar ou não contra a Igreja Católica. Pelo teor da Declaração de 26/11/1983, a Igreja Católica parece ainda não estar disposta a reconciliar-se com os maçons, não obstante o abrandamento trazido pelo novo Código de Direito Canônico e a ausência de pronunciamentos por parte da Igreja em relação aos maçons.

No entanto, é importante ter em mente que a Maçonaria condenada por Clemente XII não é a mesma existente nos dias atuais. Nem mesmo a Igreja Católica parece defender literalmente os mesmos princípios de outrora. De qualquer forma, já vai longe o tempo em que maçons e católicos trocavam ofensas públicas e se envolviam em arrastadas disputas.

Nos dias atuais, o que há, na realidade, é um grande número de maçons que professam a fé católica e um grande número de católicos filiados à Maçonaria, esperançosos em ver num futuro breve as duas instituições definitivamente reconciliadas.

\section{Referências}

ALMÉRI, T. M. Posicionamento da instituição maçônica no processo político ditatorial brasileiro (1964): da visão liberal ao conservadorismo. Dissertação (Mestrado em Sociologia). Pontifícia Universidade Católica de São Paulo, São Paulo, 2007.

AZEVEDO, C. M. M. Maçonaria: história e historiografia. Revista da USP, São Paulo, n. 32, p. 178-189, 1996-97.

ASLAN, N. História geral da maçonaria: fatos da maçonaria brasileira. Londrina: A Trolha, 1997.

BARATA, A. M. Luzes e sombras: a ação dos pedreiroslivres brasileiros (1870-1910). Dissertação (Mestrado em História) - Universidade Federal Fluminense, Niterói, 1992.

A maçonaria e a ilustração brasileira. História,

Ciência, Saúde - Manguinhos, v.1, n.1., p. 78-99, jul.out.,1994. 
. Maçonaria, sociabilidade ilustrada \& independência do Brasil (1720-1822). Juiz de Fora: UFJF; São Paulo: Annablume, 2006.

BENIMELI, J. A. F.; CAPRILE, G.; ALBERTON, V. Maçonaria e igreja: ontem, hoje e amanhã. 4.ed. São Paulo: Paulus, 1998.

COLUSSI, E. L. Plantando ramas de acácia: a maçonaria gaúcha na segunda metade do século XIX. Tese (Doutorado em História). Porto Alegre: Pontifícia Universidade Católica do Rio Grande do Sul, 1998.

GRANDE ORIENTE DO BRASIL. Disponível em: $<$ http:// www.gob.org.br>. Acesso em: 23 de maio de 2011.

HAYWOOD, H. L. Capítulos de história maçônica. Disponível em: <http://bibliotec3ca.files.worpress.com>. Acesso em: 13 jun. 2011.

HORTAL, J. Maçonaria e igreja: conciliáveis ou inconciliáveis? São Paulo: Paulus, 2002. (Coleção Estudos da CNBB, v. 66).

MOREL, M.; SOUZA, F. J. O. O poder da maçonaria: a história de uma sociedade secreta no Brasil. Rio de Janeiro: Nova Fronteira, 2008.

SILVA, M. J. D. Moderno-espiritualismo e espaço público republicano: maçons, espíritas e teosofistas no Ceará. Tese (Doutorado em Sociologia). Universidade Federal do Ceará, Fortaleza, 2009.

SOUZA, P. I. G. Buscadores do sagrado: as transformações da maçonaria em Belém do Pará. Tese (Doutorado em Ciências Sociais). Universidade Estadual de Campinas, São Paulo, 2006.

VIEIRA, D. G. O protestantismo, a maçonaria e a questão religiosa no Brasil. 2 ed. Brasília: Editora UnB, 1980.

Recebido em: 30/09/2011

Aprovado para publicação em: 09/04/2012 